\title{
The Importance of the Services Brand in Predicting Loyalty and Word of Mouth
}

\author{
Mario Alguacil ${ }^{1}$, Juan Manuel Nunez-Pomar ${ }^{1}$, Irena Valantine $^{2}$, Josep Crespo-Hervas ${ }^{1}$, Carlos \\ Perez-Campos ${ }^{3}$, Inga Staskeviciute-Butiene ${ }^{2}$
}

${ }^{1}$ University of Valencia

FCAFE, Gasco Oliag, 3, 46010 Valencia, Spain

E-mail.aljima@alumni.uv.es,josep.crespo@uv.es,juan.m.nunez@uv.es

${ }^{2}$ Lithuanian Sports University

Sporto st., 6, Kaunas, Lithuania

E-mail.irena.valantine@lsu.lt,inga.staskeviciute@lsu.lt

${ }^{3}$ Catholic University of Valencia

Sacre Cor, 5, 46113, Godella, Spain

E-mail.carlos.perez@ucv.es

cross $^{\text {ref }}$ http://dx.doi.org/10.5755/j01.ee.29.4.17694

This research is related to brand perception and its implications for the management of services, especially for hedonic services. The aim of this study is to analyse the influence of perceived brand quality on credibility and attitudes towards this perceived quality from the point of view of users, as well as whether that relationship could trigger increased loyalty and recommendations. The survey was conducted with users of a public sports service located in Valencia, Spain, and the analysis of the data and the creation of the structural model was carried out using structural equation modeling (SEM). Its results have confirmed the influence of perceived quality on credibility but not on attitudes. On the other hand, the effects of credibility and attitudes on loyalty have been significant because of the influence of credibility on recommendations and attitudes. Conversely, attitudes have not had a direct influence on the word of mouth (WOM). This type of study, represent a novel contribution, because the studies of brand perception in sports services are practically non-existent, especially in the case of public sports services. In addition, the fact of using this type of methodology is in line with the most current works. Therefore, it supposes to contribute relevant information to the bibliography of this topic, and at the same time, it provides valuable information for managers, because if they have more information about how the variables are related and to what extent they do it, they will have more and better tools to be able to manage sports services more effectively and with less expenditure of resources, being able to plan more precisely the actions that they consider appropriate.

Keywords: Brand; Perceived Quality; Loyalty; WOM, Hedonic Services.

\section{Introduction}

Consumers who intend to purchase a new product or service have many suppliers from whom to obtain information, compare, and choose from (i.e., select the one that best suits their needs). The large number of offers and the ease with which consumers can access them, analyse them, and change them is generating more demanding clients. Furthermore, this phenomenon is forcing companies to make a greater effort towards meeting the customers' needs and creating something different from their competitors, which allows them to attract new customers and keep current ones. This situation also occurs in sports services, where user exigencies have grown in proportion to the sports market growth.

The sports industry has experienced a great growth in recent years, becoming a very important sector in some countries, in economic terms (in Spain it represents $2 \%$ of GDP) and above all in employment data (Ratten, 2018). The latest statistics provided by the European Commission (2013) show that sport generates $1.76 \%$ of gross value added and $2.12 \%$ of employment in the European Union. The data shown, indicate the great importance of sport and its potential to become a relevant industry, at the level of other more traditional industries such as the automobile or publishing industry. This growth means that there is a great demand for sport at the service level, so studies such as the one carried out here, allow us to draw conclusions for services in general and, above all, for the hedonic and leisure services industry. Upon reaching a point at which the user demands are satisfied but the company offers similar services as their competitors, brand image is very important for differentiation from competitors. As a brand, we need to evoke favourable and unique associations, and these different kinds of associations can affect how we operate in the marketplace (Brexendorf \& Keller, 2017). Brand image is defined as the set of meanings that allow an object to be known and through which people describe, remember, and relate (Dowling, 1986). It is a powerful tool, of which companies are aware, and it is important to try to improve it and keep a track of the process, because consumer's behaviour is affected by brand image (Burmann et al., 2008) so it is a key element to take into account.

The process of the creation and development of brand image has benefited from the rise of new technologies and 
social networks, which allows companies to have a flow of fast and easy communication with current and potential users and manage their relationship with them. This communication allows companies to make that relationship stronger and more durable, which, in terms of marketing, is known as CRM or customer relationship management, having an important link with loyalty (Carmen \& Marius, 2016; Nyadzayo \& Khajehzadeh, 2016). This process is obviously beneficial for companies because it allows for greater capacity for and ease of reaching the user and receiving feedback. At the same time, this process is inconvenient because the access of competitors to these benefits is equal. On the other hand, these actions are also beneficial for consumers, who now that have a direct and fast connection to the brand to express their views, interact and even participate in decisions concerning future company products. These actions may contribute to the process of cocreation, whereby value is generated on both sides as long as the consumer is able to customize their experience in the use of products or services and engage in specific tasks that companies offer (Piligrimiene et al., 2016).

When we talk about benefits of a working brand, we do not only mean the economic aspect, as it is not unique to the profit organizations. Other types of entities, such as non-governmental organization or public administrations, also resort to these activities in order to convey a better image, increase the perceived quality, or be more effective by linking users to different arising projects.

One of the problems linked to services, in terms of branding work, is that unlike goods, they suffer from intangibility, the provider offers a performance promise, which is intangible (Moeller, 2010) and this, along with the rest of elements within the well-known IHIP characteristics (heterogeneity, inseparability and perishability) makes it more difficult to evaluate. To alleviate the effect of this drawback, service brands are focused on simplifying the transmission of information with users, trying to use those aspects of service that may be useful to make them tangible. Some of these aspects may include the equipment in a sport centre (Parasuraman et al., 1985), merchandising, or the promotion of good treatment between customers and staff, who are an important and influential part in the opinion that users have about a service and who make the values of the brand palpable.

In short, many aspects can make a person feel more or less disposed to a brand, and many aspects also aid in customer loyalty after the good has been consumed or service has been completed. The purpose of this study is to provide information for a better understanding of the process of brand perception in services, and its relation to important variables for services management. Therefore, we want to contribute to help managers to know where they have to focus their efforts and investments, making their actions more effective and efficient, and consequently giving to users what they were looking for. This article describes some of the most important aspects of the brand, such as perceived quality, credibility, attitudes, loyalty, and Word of Mouth to test a model for observing the relationships established between the different factors, all framed in the field of sport facilities, particularly in public sports services.

\section{Literature Review and Hypotheses}

Perceived Quality. Perceived service quality can be defined as the view of the user on the level of excellence of a product (Zeithaml, 1988). The definition of this concept revolves around a common idea or vision, which refers to quality as the result after comparing what customers expect of the service and how they receive that service (Gronroos, 1984; Parasuraman et al., 1985, 1988).

Quality is a concept widely used by consumers in all areas, also in sports, but it can create confusion since in some cases, it can be difficult to define. The concept of quality is not so simple to understand, and the difficulty to delimit it is accentuated when we want to do it in the area of services because of the aforementioned intangibility. Unlike physical goods, there are little to no visible elements to observe, in order to make the valuation process easier. Perceived quality is a concept that may have objective elements to help to value it, but it remains a perception and thus brands can work to improve it.

It should also be noted that quality, unlike satisfaction, requires no previous experience with the brand or service to be perceived. Therefore, if a company is able to make its users perceive the brand as good quality, it will be more successful than those who do not obtain those associations, even if the product of the latter is objectively better because users in many cases do not have the ability to determine whether a product is better or worse than another.

In connection with the influences that can affect quality on other aspects, we found a remarkable link with loyalty. The connection between quality and loyalty has been studied by several authors, including Boulding et al. (1993), who found that there was a positive relationship between quality that had been perceived in service and repurchase intentions. The concept of quality has been investigated in different fields of services, such as in the case of airlines (Chang \& Yeh, 2002); however, if we focus on the sports field, we see a difference in the studied topics. For example, the research has included the perceived quality of the event (Crespo et al., 2012), perceived quality in leisure centres (Murray, Howat, 2002; Wakefield \& Blodgett, 2016), or its relationship with sports tourism (Thwaites, 1999). These different lines of research have led to the creation of new instruments of measurement and their validations, such as in the case of the EVENTQUAL scale (Calabuig-Moreno et al., 2016), which is a tool for measuring the perceived quality sporting events from the point of view of spectators. This type of tools bring richness to the literature on this subject and contribute to greater understanding of the construct in its various aspects.

H1: Perceived quality significantly influences credibility.

$\mathrm{H} 2$ : Perceived quality significantly influences attitudes towards the brand.

Brand Credibility. Brand credibility is defined as the believability of an entity's intentions at a particular time (Swait \& Erdem, 2007). In order to create brand credibility, it is necessary that consistency, clarity of the brand and investment over time be increased through all practices and aspects of marketing communications such as 
brand image advertising, sponsorship, or sales promotion (Jeng, 2016). Erdem and Swait (2004) show that the views of users and their considerations when they make a particular purchase are clearly influenced by credibility, so this aspect is very important in achieving future success in a company. Some aspects, such as time sensitivity and cumulative nature, characterize the company's credibility. In terms of time sensitivity in brand credibility, a consumer's perception of credibility today may be very different from the credibility that they will perceive a week later because it is a concept of variable nature. In terms of cumulative nature in brand credibility, the credibility of a brand is the cumulative effect of the actions that have been carried out over time and is not the effect of an isolated action of marketing (Erdem et al., 2002).

Moreover, brand credibility is not only trying to attract users but also the need to continue responding to the problems that may arise, avoiding losing the credibility from current customers (Bougoure et al., 2016). On the other hand, as Sobel (1985) suggests, if we want credibility, which can be perceived by users and have a significant impact, this must precede the actions that are carried out as a company. Therefore, to be really influential, we must be credible and able to show more users other benefits of our services.

Within the concept of credibility, several authors have agreed on dividing it into the following two aspects: trustworthiness, which would be the will of the company to deliver what it promises; and expertise, which refers to the ability of the company to carry out that intention (Erdem, Swait, 2004). According to these authors, trustworthiness is up to three times more important than expertise. Although both aspects are important, it is essential to show that you want to keep promises even more than show that you are able to do so. This brand credibility and acceptance are evaluated based on the following three dimensions, originally outlined by Ameri and Behnam (2014): experience of the organization, the reliability of the organization and the organization's attractiveness or convenience. If a company or organization is appropriate, innovative (i.e., experience), reliable, and able to attract long-term users (i.e., reliability) as well as attractive, entertaining, and worth its price (i.e., attractive or convenience), it will enjoy credibility from consumers. Brand credibility could be considered a key predictor in understanding future user behaviour, and consequently, it has been analysed in different areas and from different perspectives. We have found articles that study its role in the Chinese automotive industry ( $\mathrm{Li}$ et al., 2011) to influence consumer loyalty and improve word of mouth (Sweeney \& Swait, 2008).

H3: Brand credibility significantly influences attitudes.

$\mathrm{H} 4$ : Brand credibility significantly influences loyalty.

H6: Brand credibility significantly influences word of mouth.

Attitudes towards the brand. With the help of advertising, brands convey to users their features and benefits and that information reaches customers who, after analysing and evaluating, begin to create attitudes (i.e., positive or not) for that brand (Low \& Lamb, 2000). Brand attitude can be understood as the disposition that a customer has to a brand when known, without requiring use beforehand. It is the psychological tendency that is expressed when evaluating a certain entity with a certain degree of agreement or disagreement (Eagly \& Chaiken, 2007). Later, once the users decide to use the brand, if the experience satisfied them, those positive attitudes will be enhanced and will benefit the relationship between customers and brand, which can help to increase the likelihood of purchase intentions. It has been proven that the general perception of the brand is connected to attitudes (Ko \& Kim, 2014) and that attitudes have a positive impact on future purchase intentions (Shah et al., 2012).

Attitudes towards a brand will also be affected by social influence, as claimed by Keng et al. (2016). This aspect makes users have different attitudes and intentions of purchase due to the presence (i.e., physical or virtual) of other users in the context of purchase, either interacting with them or just with their mere presence.

Related to other aspects, several authors have studied the possible relationships that could affect attitudes towards the brand based on other users' behaviour. Nearly two decades ago, Farr and Hollis (1997) argued that attitudes are a precedent for future behaviour, and the fact of creating positive attitudes towards the brand is essential for long-term business success.

H5: Attitudes significantly influence loyalty.

H7: Attitudes significantly influence word of mouth.

Loyalty. Loyalty is a key element in the user-company relationship. The fact that customers are loyal, which makes them continue using the service, is the objective of any business. On the other hand, having loyal customers makes the company enjoy stability, and to some extent, not be continually striving to find new customers and trying to retain them. In recent decades this aspect of loyalty has been studied mainly from two perspectives: behavioural loyalty and attitudinal loyalty (Dick \& Basu, 1994). The former, behavioural loyalty or purchase loyalty, is related to the repeat of the purchase of the brand; whereas, the latter, attitudinal loyalty, includes a degree of dispositional commitment (Chaudhuri \& Holbrook, 2001).

Other definitions suggest that there is loyalty when favourable attitudes are greater and when there is a process of repetition of the same pattern (Dick \& Basu, 1994). Oliver (1999) states that loyalty is the profound intention of buying steadily in the future, while in more current definitions, we find contributions, such as John (2011), where the author understands loyalty as the feeling that makes consumers buy a product, service, or brand again and again. We must not forget that the fact that users are loyal is not only because of the functional benefits, but also the symbolic aspects are very influential (O'loughlin \& Szmigin, 2006).

Within the construct of loyalty, we found a conceptual difference between brand loyalty and inertia of purchase. It is true that when there is a phase of loyalty, there exists good disposition and inertial repurchasing patterns, which develop and facilitates loyalty behaviours (Evanschitzky \& Wunderlich, 2006). However, inertia is related to spurious 
loyalty and occurs when users show behavioural, but not attitudinal loyalty (Dick \& Basu, 1994). This action occurs when they repeat purchases of the same brand in a passive way, without much thought (White \& Yanamandram, 2004). Therefore, to be regarded as true loyalty, apart from the behaviour repurchase, there must be a psychological implication that will result in a commitment to the company. In order to achieve this implication, Pappu and Quester (2016) agree that brands must consider innovation as a key element. Once that commitment takes place, we will have more loyal customers, which will increase profits because of their repurchase intentions and also could attract new customers if they recommend the goods or services in a positive way.

In the field of loyalty, there have been studies on various subjects, including loyalty to a bank (Van EsterikPlasmeijer \& Van Raaij, 2017), loyalty in choosing destinations for travel (Yolal et al., 2017), loyalty to shops (Kim et al., 2017), or loyalty to professional sports teams (Kunkel et al., 2016).

H8: Loyalty significantly influences Word of mouth.

Word of mouth. In the sport industry, it is common to see organizations involved to try to enhance WOM among their users (Asada \& Ko, 2016). When a person makes use of a service, he or she obtains an opinion about the service and that opinion (which can be satisfactory or not) could be transmitted to their acquaintances. In addition, word of mouth is something well known because when you talk about a brand in a close circle, it is common for anyone who has had experience with it to advise or discourage their use. Therefore, Word of mouth is an opinion and recommendation that may end up being an influential tool in the behaviour of others with respect to goods or services.

In the literature, word of mouth is defined as informal advice (East et al., 2008) made to one person from another over a good or service that has been used. It also includes thoughts and ideas shared by people from their own events or experiences (Mikkelsen et al., 2003). Previous studies show how word of mouth is directly influenced by proportional loyalty levels, depending on the loyalty held by those responsible for word of mouth (Kumar \& Shah, 2004). Authors, such as Wang et al. (2010), have suggested this possibility and have also established that, depending on the levels of satisfaction, it is possible to find higher or lower levels of loyalty capable of positively influencing word of mouth.

\section{Methods}

Sample and procedure. A survey was performed with the intention to test a model and see the relationship between different factors related to the brand in this study. Data collection was performed in a public sports service in the city of Valencia, Spain, and the sample was selected by non-probabilistic sampling of intentional or convenience type, obtained from the users (i.e., over 18 years of age) who use the facilities of the municipal sports' service more or less frequently. Once the sample was analysed, it was found that $29.4 \%$ of respondents were between 18 and 25 years old, which comprised the majority of users, followed by age ranges $26-35(27.4 \%), 36-45$ (20.1\%), 46-55 $(13.2 \%)$ and over $55(9.8 \%)$. An average age of 35.58 years (SD 13.37) was obtained, consisting mostly of women $(53.8 \%)$. The total sample comprised 210 users, of which $57.2 \%$ made use of the service 3 or more times a week.

Measures. We developed a questionnaire based on studies with a similar theme, consisting of a list of items intended to measure the opinion of users on different aspects. It was divided into different coded sections made up of the following nine factors: attitudes, credibility, brand equity, brand personality, loyalty, consistency, Word of Mouth, service satisfaction and perceived quality. The study variables used for the proposed model were the five detailed in the theoretical framework (perceived quality, credibility, brand attitude, loyalty and Word of Mouth). Once the questionnaire was drawn up and reviewed by the research group in sports management at the University of Valencia, the questionnaire was administered in a personal and incidental way among the users of the sports services. The first part of the questionnaire consisted of statements about the brand and service, where users responded using the Likert scale according to their degree of agreement or disagreement with the statement (i.e., 1 = strongly disagree and $5=$ strongly agree). The last part of the survey included questions used for collecting socio-demographic data.

We then provided details on the items and sources that were used to develop the scales of analysed constructs in order of appearance on the survey. As the scope was not the same as the original, due to lack of specific literature, statements were adapted to ask about the purpose of the study, which analysed the brands of sports services. First, we determined the attitudes towards the brand, which was made up of 4 items collected from Gwinner and Bennet (2008). Then, we obtained a score for the following items on a scale 1 to 3 , corresponding with the following statements: I like the brand " $X$ "; " $X$ " is a very good brand; I have a favourable disposition towards " $\mathrm{X}$ " brand.

A fourth item was taken from Besharat (2010): My attitude towards this brand is very positive.

The second dimension corresponds to brand credibility, and within it, there are 3 items that have been obtained from the study about the effects of credibility on loyalty according to Sweeney and Swait (2008): (Service brand) delivers what it promises; $X$ claims about its service are believable; $X$ has a name you can trust.

The third dimension, which is part of the proposed model, is loyalty. To build this section, we used the scale of Yoo and Donthu (2001), which contains the following statements: I consider myself to be loyal to X; X would be my first choice; I will not buy other brands if $\mathrm{X}$ is available at the store.

The fourth dimension is related to Word of mouth. This part has four items that have been collected from two different studies. The first is Tong and Hawley (2009) from which we extract the first item: I would love to recommend $\mathrm{X}$ to my friends.

While the following three statements that complete this scale are the result of an adaptation from the original Hightower et al. (2002) study: I will recommend this sports center to my friends and family; I will speak positively about this sports center to other people if asked; I will encourage other people to go to this sports center. 
Finally, the fifth dimension that appears is the perceived overall quality. The items in this section have been obtained from Yoo and Donthu (2001), including the following statements: This is a high-quality sporting service; it is likely that the quality of this service is extremely high.

\section{Results}

Measurement model. A confirmatory factor analysis (CFA) was performed to test the reliability and validity of the constructs. Regarding the goodness of fit of the model, a Satorra-Bentler scaled Chi-squared value of 136.71 with 94 degrees of freedom was obtained, which provides a result of $\mathrm{X} 2 / \mathrm{gl}=1.45$ for the ratio, which is below 3 , and is therefore considered as good (Kline, 1998). In relation to the value of adjustment, indices were all higher than the criterion of 0.90 (Browne \& Cudeck, 1993; Hu \& Bentler, 1999) with the following results: NFI (0.94), NNFI (0.97), CFI (0.98) and IFI (0.98).

We can confirm that the RMSEA (root mean square error of approximation) met the established criteria because its value is 0.047 , which is below 0.08 , so an appropriate fit between measurement model and data was achieved (Browne, Cudeck, 1993; Hu, Bentler, 1999). By contrast, the coefficient of Mardia, which estimates the multivariate normality of the data by evaluating the multivariate kurtosis, did not obtain an acceptable result, as it exceeded 3, which is considered the limit to indicate there is no normality (Bentler, 2001). For that reason, we had to attend to the data obtained using the robust analysis method.

After analysing the results of convergent validity, the values of composite reliability (CR) and average variance extracted (AVE) for the perceived quality were 0.88 (CR) and 0.70 (AVE). On the other hand, in the variable credibility, they were 0.89 (CR) and 0.72 (AVE), while for attitudes towards the brand, they were 0.90 (CR) and 0.69 (AVE). Meanwhile, loyalty showed a result of 0.86 (CR) and 0.67 (AVE). Finally, Word of mouth obtained values of 0.94 (CR) and 0.84 (AVE). Convergent validity has been adequate in each element of the proposed structural model, with AVE values greater than 0.50 (Fornell \& Larcker, 1981) and composite reliability values higher than 0.70 (Hair et al., 2006). Table 1 shows a summary of data for each construct and also the values of $\mathrm{R} 2$.

Table 1

Convergent Validity

\begin{tabular}{|c|c|c|c|c|}
\hline Construct & Items & $\begin{array}{l}\text { Composite } \\
\text { Reliability }\end{array}$ & $\begin{array}{l}\text { Average variance } \\
\text { extracted }\end{array}$ & $\mathbf{R} 2$ \\
\hline \multirow{4}{*}{$\begin{array}{l}\text { Brand Attitude } \\
\text { (F3) }\end{array}$} & 1 & \multirow{4}{*}{0.90} & \multirow{4}{*}{0.69} & .689 \\
\hline & 2 & & & .763 \\
\hline & 3 & & & .691 \\
\hline & 4 & & & .619 \\
\hline \multirow{3}{*}{$\begin{array}{l}\text { Brand Credibility } \\
\text { (F2) }\end{array}$} & 10 & \multirow{3}{*}{0.89} & \multirow{3}{*}{0.72} & .798 \\
\hline & 11 & & & .749 \\
\hline & 12 & & & .616 \\
\hline \multirow{3}{*}{$\begin{array}{l}\text { Brand Loyalty } \\
\text { (F4) }\end{array}$} & 46 & \multirow{3}{*}{0.86} & \multirow{3}{*}{0.67} & .620 \\
\hline & 47 & & & .774 \\
\hline & 48 & & & .617 \\
\hline \multirow{4}{*}{$\begin{array}{l}\text { WOM } \\
\text { (F5) }\end{array}$} & 56 & \multirow{4}{*}{0.94} & \multirow{4}{*}{0.84} & .810 \\
\hline & 57 & & & .818 \\
\hline & 58 & & & .890 \\
\hline & 59 & & & .585 \\
\hline \multirow{2}{*}{ Quality (F1) } & 61 & \multirow{2}{*}{0.88} & \multirow{2}{*}{0.70} & .734 \\
\hline & 63 & & & .794 \\
\hline
\end{tabular}

Model and structural hypotheses. The questionnaire for conducting this study consists of a total of 9 constructs, as follows: brand attitude, credibility, brand equity, brand personality, loyalty, congruence, WOM, satisfaction, and overall perceived quality. As previously mentioned, to create this structural equation model, which would be the main part of the study, 5 dimensions were used (Figure 1). Due to the possible relationships that may exist between these factors, research hypotheses $\mathrm{H} 1$ to $\mathrm{H} 8$ arise.

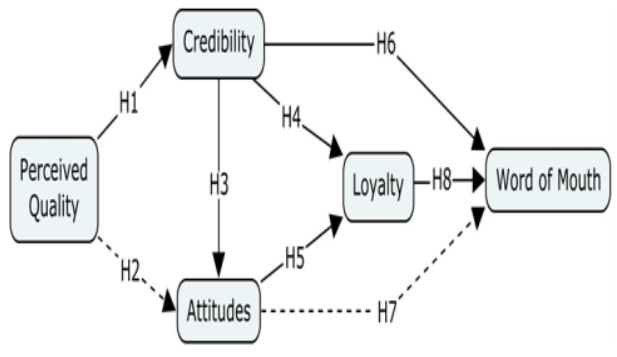

Figure 1. Structural Model of Hypothesis

The results of hypotheses (Table 2) show that the relationship between quality and credibility is significant (b $=0.82, \mathrm{t}=10.73$ ), which supports $\mathrm{H} 1$; while on the contrary, quality and attitudes show no significant relationship ( $\mathrm{b}=$ $0.21, \mathrm{t}=1.87$ ) so $\mathrm{H} 2$ is not supported. In the relationship between credibility and attitudes (H3), credibility and loyalty (H4), and attitudes and loyalty (H5), significant relationships were obtained in all of them $(b=0.63, t=5.41$, $\mathrm{b}=0.34, \mathrm{t}=3.09, \mathrm{~b}=0.50, \mathrm{t}=4.39$, respectively). Finally, it is noted that the relationship between credibility and word of mouth and the relationship between loyalty and word of mouth are both significant, supporting $\mathrm{H} 6$ and $\mathrm{H} 8(\mathrm{~b}=0.35$, $\mathrm{t}=2.68, \mathrm{~b}=0.55, \mathrm{t}=4.88$, respectively). Conversely, the relationship between attitudes and Word of mouth that forms $\mathrm{H} 7$ did not demonstrate significance $(\mathrm{b}=-0.22, \mathrm{t}=-0.17)$, making that hypothesis unsupported.

Table 2

Hypothesis Results

\begin{tabular}{|l|c|c|c|}
\hline \multicolumn{1}{|c|}{ Hypothesis } & $\begin{array}{c}\text { Standardized } \\
\text { Coefficient (Beta) }\end{array}$ & T Value & Conclusion \\
\hline $\begin{array}{l}\text { H1: Quality- } \\
\text { credibility }\end{array}$ & 0.82 & $10.73^{* *}$ & Supported \\
\hline $\begin{array}{l}\text { H2: Quality- } \\
\text { attitudes }\end{array}$ & 0.21 & 1.87 & Unsupported \\
\hline $\begin{array}{l}\text { H3: } \\
\text { Credibility- } \\
\text { attitudes }\end{array}$ & 0.63 & $5.41^{* *}$ & Supported \\
\hline $\begin{array}{l}\text { H4: } \\
\text { Credibility- } \\
\text { loyalty }\end{array}$ & 0.34 & $3.09^{* *}$ & Supported \\
\hline $\begin{array}{l}\text { H5: Attitudes- } \\
\text { loyalty }\end{array}$ & 0.50 & $4.39^{* *}$ & Supported \\
\hline $\begin{array}{l}\text { H6: } \\
\text { Credibility- } \\
\text { WOM }\end{array}$ & 0.35 & $2.68^{* *}$ & Supported \\
\hline $\begin{array}{l}\text { H7: Attitudes- } \\
\text { WOM }\end{array}$ & -.022 & -0.17 & Unsupported \\
\hline $\begin{array}{l}\text { H8: Loyalty- } \\
\text { WOM }\end{array}$ & 0.55 & $4.88^{* *}$ & Supported \\
\hline
\end{tabular}

Implications, limitations and future research. The results of this research are helpful in understanding the 
influence of the brand of hedonic services in the performance of the company in terms of user perception. This knowledge can help establish a set of predictors that serve to understand certain user behaviours in the future and also to show what aspects affect others, permitting knowledge of the most relevant aspects when attempting to achieve the objectives of the service. Therefore, analysis of brand perception provides valuable information for managers, and they are beginning to become aware of this concept, which is why an increasing number of services analyse and work their own brand, trying to provide customers with brand value to generate loyalty and increase purchase intentions and recommendations. In addition, analysis of brand perception not only has benefits in terms of repurchase of service and recommendations but also saves costs by making efficient investments since it allows a company to identify those aspects and to concentrate efforts on those aspects that have been proven as influential in modifying the behaviour of users and that are necessary to achieve our goals.

All research work has certain limitations that should be highlighted and considered. The main limitation of this work is in the sample studied, since it is not very large, which also refers to a specific sports' service. Although this limitation is common in this type of study, it would be very interesting to work with a larger sample and take in different sports services so that any difference between the different types of services can be analysed. Moreover, it would be interesting to investigate sports services that make an effort to improve the brand image and others that do not, and thus, to see if the future intentions of the users depend on the same or different factors.

Finally, an interesting future research study would be to analyse the influence of brand attributes on the future intentions of users in both public and private sports services after efforts are made to improve the service brand. This study would help in determining if the type of ownership has any influence on the valuation of the service provided.

\section{Discussion and Conclusions}

As mentioned above, the sport business is gaining great relevance in developed countries, and the conclusions of this study may be applicable to improve the service industry in general, but especially hedonic services.
In this study, we analyse how brand perception can trigger higher levels of loyalty and recommendation, including with the classic variables of quality, loyalty and recommendation, brand aspects that have shown their influence on these variables. Therefore, they provide evidence of the importance of the work of the brand to improve profitability in these types of companies, so they must be taken into account. Specifically, we investigated the influence of the brand quality perceived on aspects of credibility and the attitudes towards the brand. We also determined what actions of a company influence the future behaviours of the users, whether in the shape of loyalty towards the service or recommendations. The results indicate that the perceived quality positively influences the perception of credibility of the consumer, but not the users' attitudes towards this brand. The credibility significantly influences the users' attitudes towards the brand, and both affect the users' loyalty.

On the other hand, it has been observed that credibility directly affects Word of Mouth while attitudes do not show significant influence. Finally, loyalty has been shown to have a significant influence on WOM. From the applied point of view, this study provides a contribution to the scientific literature on the perception of brand in the hedonic and leisure services industry, in general, and specifically in sport services, which has been studied little by the marketing service providers. Besides, it provides an approach with a not very common methodology in this area such as the structure equation modeling (SEM), which allows the creation of structural models to understand the relationships and influences between variables. Speaking about managerial implications, this type of article responds to the increasing interest of service managers to know how brand image can serve them to be better perceived, to deliver a better service and to be able to differentiate themselves from other companies, which can give them that competitive advantage within the great offer that exists in the market and therefore increase their profits. In order with this, we think that future research lines of this topic should continue to be carried out to provide new information, of these variables, and also of others that may be influential. It would also be interesting to analyse the possible differences that can be found in the models created based on the type of service management.

\section{References}

Ameri, H. S., \& Behnam, M. (2014). The effect of brand credibility on consumers' perception about brands and their purchasing behaviors in sport goods. Sport Science, 7(2), 50-57.

Asada, A., \& Ko, Y. J. (2016). Determinants of word-of-mouth influence in sport viewership. Journal of Sport Management, 30(2), 192-206. https://doi.org/10.1123/jsm.2015-0332

Bentler, P. M. (2001). EQS 6 structural equations program manual. Encino, CA: Multivariate Software.

Besharat, A. (2010). How co-branding versus brand extensions drive consumers' evaluations of new products: A brand equity approach. Industrial Marketing Management, 39(8), 1240-1249. https://doi.org/10.1016/j.indmarman.20 10.02.021

Bougoure, U. S., Russell-Bennett, R., Fazal-E-Hasan, S., \& Mortimer, G. (2016). The impact of service failure on brand credibility. Journal of Retailing and Consumer Services, 31, 62-71. https://doi.org/10.1016/j.jretconser.2016.03.006

Boulding, W., Kalra, A., Staelin, R., \& Zeithaml, V. A. (1993). A dynamic process model of service quality: from expectations to behavioral intentions. Journal of Marketing Research, 30(1), 7-27. https://doi.org/10.2307/3172510 
Mario Alguacil, Juan Manuel Nunez-Pomar, Irena Valantine, Josep Crespo-Hervas, Carlos Perez-Campos, Inga

Staskeviciute-Butiene. The Importance of the Services Brand in Predicting Loyalty and Word of Mouth

Brexendorf, T. O., \& Keller, K. L. (2017). Leveraging the corporate brand: the importance of corporate brand innovativeness and brand architecture. European Journal of Marketing, 51(9/10), 1530-1551. https://doi.org/10.11 08/EJM-07-2017-0445

Browne, M. W., \& Cudeck, R. (1993). Alternative ways of assessing model fit, in Bollen, K. A., Long, J. S. (eds.), Testing structural equation model. Newbury Park, CA, Sage, 136-162.

Burmann, C., Schaefer, K., \& Maloney, P. (2008). Industry image: Its impact on the brand image of potential employees. Journal of Brand Management, 16(3), 159-176. https://doi.org/10.1057/palgrave.bm.2550112

Calabuig, F., Crespo-Hervas, J., Prado-Gasco, V., Mundina, J., Valantine, I., \& Stanislovaitis, A. (2016). Quality of sporting events: validation of the eventqual scale. Transformation in Business \& Economics, 15(2), 21-32.

Carmen, R., \& Marius, S. (2016). Customer loyalty using customer relationship management. Management Strategies Journal, 31(1), 285-288.

Chang, Y. H., \& Yeh, C. H. (2002). A survey analysis of service quality for domestic airlines. European Journal of Operational Research, 139(1), 166-177. https://doi.org/10.1016/S0377-2217(01)00148-5

Chaudhuri, A., \& Holbrook, M. B. (2001). The chain of effects from brand trust and brand affect to brand performance: the role of brand loyalty. Journal of Marketing, 65(2), 81-93. https://doi.org/10.1509/jmkg.65.2.81.18255

Crespo, J., Perez-Campos, C., \& Mundina, J. (2012). Calidad de servicio percibida por los espectadores de fútbol. Analisis de diferencias entre grupos [Spectators' perceived service quality of a football event. Analysing differences between groups]. Journal of Sports Economics \& Management, 2(1), 4-15.

Dick, A. S., \& Basu, K. (1994). Customer loyalty: toward an integrated conceptual framework. Journal of the Academy of Marketing Science, 22(2), 99-113. https://doi.org/10.1177/0092070394222001

Dowling, G. (1986). Managing your Corporate Images. Industrial Marketing Management, 15(2), $109-115$. https://doi.org/10.1016/0019-8501(86)90051-9

Eagly, A. H., \& Chaiken, S. (2007). The advantages of an inclusive definition of attitude. Social cognition, 25(5), 582602. https://doi.org/10.1521/soco.2007.25.5.582

East, R., Hammond, K., \& Lomax, W. (2008). Measuring the impact of positive and negative word of mouth on brand purchase probability. International Journal of Research in Marketing, 25(3), 215-224. https://doi.org/10.101 6/j.ijresmar.2008.04.001

Erdem, T., \& Swait, J. (2004). Brand credibility and its role in brand choice and consideration. Journal of Consumer Research, 31(1), 191-199. https://doi.org/10.1086/383434

Erdem, T., Swait, J., \& Louviere, J. (2002). The impact of brand credibility on consumer price sensitivity. International Journal of Research in Marketing, 19(1), 1-19. https://doi.org/10.1016/S0167-8116(01)00048-9

European Commission (2013). Study on the contribution of sport to economic growth and employment. Retrieved from: http://ec.europa.eu/assets/eac/sport/library/studies/study-contribution-spors-economic-growth-final-rpt.pdf

Evanschitzky, H., \& Wunderlich, M. (2006). An examination of moderator effects in the four-stage loyalty model. Journal of Service Research, 8(4), 330-345. https://doi.org/10.1177/1094670506286325

Farr, A., \& Hollis, N. (1997). What do you want your brand to be when it grows up: big and strong? Journal of Advertising Research, 36(6), 23-36.

Fornell, C., \& Larcker, D. (1981). Evaluating structural equation models with unobservable variables and measurement error. Journal of Marketing Research, 18(1), 39-50. https://doi.org/10.2307/3151312

Gronroos, C. (1984). A service quality model and its market implications. European Journal of Marketing, 18(4), 36-44. https://doi.org/10.1108/EUM0000000004784

Gwinner, K., Bennet, G. (2008). The impact of brand cohesiveness and sport identification on brand fit in a sponsorship context. Journal of Sport Management, 22(4), 410-426. https://doi.org/10.1123/jsm.22.4.410

Hair, J. F., Black, W. C., Babin, B. J., Anderson, R. E., \& Tatham, R. L. (2006). Multivariate data analysis (6th ed.), Upper Saddle River, NJ, Pearson Prentice Hall.

Hightower, R., Brady, M. K., \& Baker, T. L. (2002), "Investigating the role of the physical environment in hedonic service consumption: an exploratory study of sporting events". Journal of Business Research, 55(9), 697-707. https://doi.org/10.1016/S0148-2963(00)00211-3

Hu, L. T., \& Bentler, P. M. (1999). Cutoff criteria for fit indexes in covariance structure analysis: Conventional criteria versus new alternatives. Structural Equation Modeling: A Multidisciplinary Journal, 6(1), 1-55. https://doi.org/10.10 80/ 10705519909540118

Jeng, S. P. (2016). The influences of airline brand credibility on consumer purchase intentions. Journal of Air Transport Management, 55, 1-8. https://doi.org/10.1016/j.jairtraman.2016.04.005 
John, J. (2011). An analysis on the customer loyalty in telecom sector. Special reference to Bharath Sanchar Nigam limited, India. African Journal of Marketing Management, 3(1), 1-5.

Keng, C. J., Chang, W. H., Chen, C. H., \& Chang, Y. Y. (2016). Mere virtual presence with product experience affects brand attitude and purchase intention. Social Behavior and Personality, 44(3), 431. https://doi.org/10.2224/ sbp.2016.44.3.431

Kim, S. H., Kim, M., \& Holland, S. (2017). How customer personality traits influence brand loyalty in the coffee shop industry: the moderating role of business types. International Journal of Hospitality \& Tourism Administration, 1-25.

Kline, R. B. (1998). Principles and practice of structural equation modeling. New York, NY: The Guilford Press.

Ko, Y. J., \& Kim, Y. K. (2014). Determinants of consumers' attitudes toward a sport sponsorship: a tale from college athletics. Journal of Nonprofit \& Public Sector Marketing, 26(3), 185-207. https://doi.org/10.1080/1049 5142.2014.899811

Kumar, V., \& Shah, D. (2004). Building and sustaining profitable customer loyalty for the 21st Century. Journal of Retailing, 80(4), 317-330. https://doi.org/10.1016/j.jretai.2004.10.007

Kunkel, T., Doyle, J. P., Funk, D. C., Du, J., \& McDonald, H. (2016). The development and change of brand associations and their influence on team loyalty over time. Journal of Sport Management, 30(2), 117-134. https://doi.org/10.1 123/jsm.2015-0129

Li, Y., Wan, X., \& Yang, Z. (2011). The effects of corporate-brand credibility, perceived corporate-brand origin, and selfimage congruence on purchase intention: evidence from China's auto industry. Journal of Global Marketing, 24(1), 58-68. https://doi.org/10.1080/08911762.2011.545720

Low, G., \& Lamb, C. (2000). The measurement and dimensionality of brand associations. Journal of Product \& Brand Management, 9(6), 350-368. https://doi.org/10.1108/10610420010356966

Mikkelsen, M., Van Durme, J., \& Carrie, D. G. (2003). Viewers talking about television advertising: a supplementary measure of advertising effectiveness. Paper presented at the 32nd EMAC, Glasgow, 20-23rd May.

Moeller, S. (2010). Characteristics of services-a new approach uncovers their value. Journal of Services Marketing, 24(5), 359-368. https://doi.org/10.1108/08876041011060468

Murray, D., \& Howat, G. (2002). The relationships among service quality, value, satisfaction, and future intentions of customers at an Australian sports and leisure centre. Sport Management Review, 5(1), 25-43. https://doi.org/10.10 16/S1441-3523(02)70060-0

Nyadzayo, M. W., \& Khajehzadeh, S. (2016). The antecedents of customer loyalty: a moderated mediation model of customer relationship management quality and brand image. Journal of Retailing and Consumer Services, 30, 262270. https://doi.org/10.1016/j.jretconser.2016.02.002

Oliver, R. L. (1999). "Whence consumer loyalty? Journal of Marketing, 63, 33-44. https://doi.org/10.2307/1252099

O'Loughlin, D., \& Szmigin, I. (2006). Emerging perspectives on customer relationships, interactions and loyalty in Irish retail financial services. Journal of Consumer Behaviour, 5(2), 117-129. https://doi.org/10.1002/cb.39

Pappu, R., \& Quester, P. G. (2016). How does brand innovativeness affect brand loyalty? European Journal of Marketing, 50(1/2), 2-28. https://doi.org/10.1108/EJM-01-2014-0020

Parasuraman, A., Zeithaml V. A., \& Berry L. L. (1988). Servqual: A multiple-item scale for measuring consumer perceptions of service quality. Journal of Retailing, 64(1), 12-40.

Parasuraman, A., Zeithaml, V. A., \& Berry, L. L. (1985). A conceptual model of service quality and its implications for future research. Journal of Marketing, 49(4), 41-50. https://doi.org/10.2307/1251430

Piligrimiene, Z., Dovaliene, A., \& Virvilaite, R. (2015). Consumer engagement in value co-creation: what kind of value it creates for company? Inzinerine Ekonomika-Engineering Economics, 26(4), 452-460. https://doi.org/10.5 755/j01.ee.26.4.12502

Ratten, V. (2018). System Processes in Sport Entrepreneurship. In: Sport Entrepreneurship. Management for Professionals. Springer, Cham. https://doi.org/10.1007/978-3-319-73010-3

Schumacker, R., \& Lomax, R., (2004). A beginner's guide to structural equation modeling (2 ${ }^{\mathrm{a}}$ ed.), Mahwah, NJ: Lawrence Erlbaum Associates. https://doi.org/10.4324/9781410610904

Shah, S. S. H., Aziz, J., Jaffari, A. R., Waris, S., Ejaz, W., Fatima, M., \& Sherazi, S. K. (2012). The impact of brands on consumer purchase intentions. Asian Journal of Business Management, 4(2), 105-110.

Sharp, B. (1995). Brand equity and market-based assets of professional service firms. Journal of Professional Services Marketing, 13(1), 3-13. https://doi.org/10.1080/15332969.1995.9985201

Sobel, J. (1985). A theory of credibility. Review of Economic Studies, 52(4), 557-573. https://doi.org/10.2307/2297732

Swait, J., \& Erdem, T. (2007). Brand effects on choice and choice set formation under uncertainty. Marketing Science, 26(5), 679-697. https://doi.org/10.1287/mksc.1060.0260 
Mario Alguacil, Juan Manuel Nunez-Pomar, Irena Valantine, Josep Crespo-Hervas, Carlos Perez-Campos, Inga

Staskeviciute-Butiene. The Importance of the Services Brand in Predicting Loyalty and Word of Mouth

Sweeney, J. C., \& Swait, S. (2008). The effects of brand credibility on customer loyalty. Journal of Retailing and Consumer Services, 15(3), 179-193. https://doi.org/10.1016/j.jretconser.2007.04.001

Thwaites, D. (1999). Closing the gaps: service quality in sport tourism. Journal of Services Marketing, 13(6), 500-516. https://doi.org/10.1108/08876049910298766

Tong, X., \& Hawley, J. M. (2009). Measuring customer-based brand equity: empirical evidence from the sportswear market in China. Journal of Product \& Brand Management, 18(4), 262-271. https://doi.org/10.1108/10610 420910972783

Van Esterik-Plasmeijer, P. W., \& Van Raaij, W. F. (2017). Banking system trust, bank trust, and bank loyalty. International Journal of Bank Marketing, 35(1), 97-111. https://doi.org/10.1108/IJBM-12-2015-0195

Wakefield, K. L., \& Blodgett, J. (2016). Retrospective: The importance of servicescapes in leisure service settings. Journal of Services Marketing, 30(7), 686-691. https://doi.org/10.1108/JSM-08-2016-0291

Wang, Y. J., Hernandez, M. D., \& Minor, M. S. (2010). Web aesthetics effects on perceived online service quality and satisfaction in an e-tail environment: The moderating role of purchase task. Journal of Business Research, 63(9/10), 935-942. https://doi.org/10.1016/j.jbusres.2009.01.016

White, L., \& Yanamandram, V. (2004). Why customers stay: reasons and consequences of inertia in financial services. Managing Service Quality: An International Journal, 14(2/3), 183-194. https://doi.org/10.1108/09604520410528608

Yolal, M., Chi, C. G. Q., \& Pesamaa, O. (2017). Examine destination loyalty of first-time and repeat visitors at allinclusive resorts. International Journal of Contemporary Hospitality Management, 29(7).https://doi.org/10.110 8/IJCHM-06-2015-0293

Yoo, B., \& Donthu, N. (2001). Developing and validating a multidimensional consumer-based brand equity scale. Journal of Business Research, 52(1), 1-14. https://doi.org/10.1016/S0148-2963(99)00098-3

Zeithaml, V. A. (1988). Consumer perceptions of price, quality, and value a means-end model and Synthesis of evidence. Journal of Marketing, 52(3), 2-22. https://doi.org/10.2307/1251446

The article has been reviewed.

Received in March, 2017; accepted in October, 2018. 